\title{
Characterization of genetic differences in hormone-induced ovulation rate in mice
}

\author{
J. L. Spearow* \\ Department of Meat and Animal Science, University of Wisconsin, Madison, WI 53706, U.S.A. and \\ Reproductive Endocrinology Program, and Department of Human Genetics, University of Michigan, \\ Ann Arbor, Michigan 48109, U.S.A.
}

\begin{abstract}
Summary. Major genetic differences in hormone-induced ovulation rate were not explained by strain differences in age at puberty, by maturation and ovulation of follicles by endogenous gonadotrophins, or by differential responses to gonadotrophins at different ages. The major genetic differences in hormone-induced ovulation rate were explained by strain differences in ovarian responsiveness to exogenous gonadotrophins.
\end{abstract}

Keywords: ovulation rate; mouse; genetic differences

\section{Introduction}

Major genetic differences in hormone-induced ovulation rate in young mice have been identified (Spearow, 1988): a comparison of parentals, $F_{1}$ and $F_{2}$ crosses, revealed that a 5-fold difference in hormone-induced ovulation rate between strains $\mathrm{A} / \mathrm{J}$ and $\mathrm{SJL} / \mathrm{J}$ was due to the action of about $2-3$ loci, and a 6-fold difference in hormone-induced ovulation rate between strains $\mathrm{A} / \mathrm{J}$ and $\mathrm{C} 57 \mathrm{BL} / 6 \mathrm{~J}$ was due to the action of about 3-4 loci. These genetic differences in hormone-induced ovulation rate at 28 days of age could have been due to genetic differences in (1) age at puberty, (2) maturation and ovulation of follicles by endogenous gonadotrophins, (3) maturation of follicles by endogenous gonadotrophins and ovulation by exogenous gonadotrophins, (4) age-dependent responses to gonadotrophins, or (5) ovarian responsiveness to exogenous PMSG and hCG. The main purpose of the present study was to determine which of the above factors was responsible for the observed genetic differences in hormone-induced ovulation rate. Since major genetic differences in hormoneinduced ovulation rate were observed in response to priming with PMSG, another purpose was to determine whether similar genetic differences were also found in response to priming with FSH.

\section{Materials and Methods}

Lines and husbandry of mice. The highly inbred strains of mice used in this study, A/J, SEC/1 ReJ, 129/SvJ, SJL/J and C57BL/6J, were obtained from the Jackson Laboratory (Bar Harbor, Maine, U.S.A.). Mice were bred, housed and managed according to the procedures of Spearow (1988). While the mice examined by Spearow (1988) were housed in a conventional mouse laboratory, the mice in the present study, except for those used in Exps 4 and 5, were maintained and housed in a specific pathogen-free laboratory. The same lot of lyophilysed gonadotrophins was used within each experiment. PMSG and oFSH-16 (FSH activity $=20 \times \mathrm{NIH}-\mathrm{FSH}-\mathrm{SI}$ per mg; LH activity $=0.04 \times \mathrm{NIH}-\mathrm{LH}-\mathrm{SI}$ per $\mathrm{mg}$ ) were from the hormone distribution program, NIADDK, National Institutes of Child Health and Human Development, Bethesda, MD. Human chorionic gonadotrophin used in Exps 3 and 5 was from Sigma Chemical Company (St Louis, MO, U.S.A.) and had an activity of 2500 i.u. per mg. The hCG used in Exp. 4 was from Hypo Lab (Cousins, Switzerland) and had an activity of 2700 i.u. per $\mathrm{mg}$. Mice within each experiment were examined in overlapping groups as they were produced in the breeding colony. Mice compared within each experiment were as contemporary as possible.

*Present address: Department of Meat and Animal Science, University of Wisconsin, Madison, WI 53706, U.S.A. 
Experiment 1 . The onset of puberty in the absence of males was determined as the day of vaginal opening. In this experiment and Exps 3 and 4 of the present study, females were weaned at 21 days of age and housed in cages separate from, but in the olfactory presence of, males. Females were checked daily with blunt forceps until the day of vaginal opening.

Experiment 2. The onset of puberty was examined in females of strains $\mathrm{A} / \mathrm{J}, \mathrm{SJL} / \mathrm{J}$ and $\mathrm{C} 57 \mathrm{BL} / 6 \mathrm{~J}$ by determining the age and weight at vaginal opening and first plug of semen found in the vagina (vaginal plug). Females were weaned at 21 days of age and housed with mature males of the same strain. Females were checked daily with blunt forceps until the date of vaginal opening and first vaginal plug.

Experiment 3. Effect of age of females when gonadotrophins were administered was examined. Female mice of strains $\mathrm{A} / \mathrm{J}$ and $\mathrm{C} 57 \mathrm{BL} / 6 \mathrm{~J}$ were injected subcutaneously with 5 i.u. PMSG in $50 \mu \mathrm{l} 0.02 \mathrm{M}-\mathrm{NaPO}, 0 \cdot 14 \mathrm{M}-\mathrm{NaCl}, 0 \cdot 1 \%$ gelatin, pH 7.2 (PBS-gel) at 3.5, 4,6 or 8 weeks of age. SJL/J mice were similarly treated at 4 and 8 weeks of age, but insufficient numbers were available for study at 3.5 or 6 weeks of age. Each female was injected subcutaneously $48-52 \mathrm{~h}$ later with 5 i.u. hCG in $50 \mu$ l PBS-gel. At 16-22 h later the mice were weighed, and killed by cervical dislocation. The number of ova with cumulus (fresh ova) and without cumulus (old ova) in the oviduct was then determined according to the procedures of Spearow (1988). Since the fresh ova were recovered in a tight cumulus clump, their recovery was essentially complete. In contrast, the recovery of the old ova seemed to be lower and more variable due to their dispersion and occasional transport through the oviduct. Since the purpose of this experiment was to determine the effect of age on induced ovulation rate, the effect of stage of cycle on hormone-induced ovulation rate was not examined.

Experiment 4. Responses to increasing doses of PMSG and a constant amount of hCG were examined in mice of strains A/J, SEC/1 ReJ, 129/SvJ, and C57BL/6J. These strains were chosen because they showed a low, medium-low, medium and high hormone-induced ovulation rate in response to 5 i.u. PMSG at 28 days and 5 i.u. hCG at 30 days of age (Spearow, 1988). At 28 days of age 0, 2 or 5 i.u. PMSG were injected in $50 \mu \mathrm{l}$ or less of PBS-gel. On Day 30, 48-52 h later, 5 i.u. hCG were injected subcutaneously in $50 \mu \mathrm{l}$ PBS-gel. The number of ova with and without cumulus, and body weight, were determined 16-22 h later on Day 31.

Experiment 5. Responses to increasing doses of oFSH and a constant amount of hCG were examined in strains $\mathrm{A} / \mathrm{J}, \mathrm{SJL} / \mathrm{J}$ and $\mathrm{C} 57 \mathrm{BL} / 6 \mathrm{~J}$. These 3 strains were chosen since they showed the extremes in hormone-induced ovulation rate in response to 5 i.u. PMSG at 28 days and 5 i.u. hCG at 30 days (Spearow, 1988). Starting at 28 days of age $0,2,4$ or $10 \mu \mathrm{g}$ oFSH were injected two times per day in $100 \mu \mathrm{l}$ PBS-gel. On Day $30,48 \mathrm{~h}$ after the first injection of FSH, 5 i.u. hCG was injected subcutaneously in $100 \mu$ l PBS-gel. The number of ova with and without cumulus, and body weight were then determined 18-20 h later on Day 31.

Statistical analysis. Results from Exps $I$ and 2 were tested with one-way analysis of variance. All untransformed and log-transformed data on number of ova, number of old ova and body weight from Exps 3, 4 and 5 were tested by one-way analysis of variance. Data on strains A/J and C57BL/6J in Exp. 3 and all strains in Exps 4 and 5 were also examined by two-way analysis of variance. Log transformation of induced-ovulation rate data substantially improved the homogeneity of variances for this trait in Exp. 3, slightly improved homogeneity of variances in induced ovulation rate in Exp. 4, but not in Exp. 5. Therefore, ANOVAs were conducted on untransformed data using the BrownForsythe test, or on log-transformed data when $\log$ transformation improved the homogeneity of variances. The Brown-Forsythe test was often indicated since it does not require the assumption of homogeneity of within group variances (Brown \& Forsythe, 1974; Dixon, 1983). Individual comparisons were made with Tukey's multiple range test in Exp. 3, the Bonferonni T-test in Exp. 4 and with Duncan's multiple range test in Exp. 5. Data on the percentage of females with fresh and old ova in the oviducts in Exp. 4 were analysed by $\chi^{2}$ test.

\section{Results}

\section{Experiment 1}

The timing of puberty was determined in the absence of males. The mean \pm s.e. ages at vaginal opening for mice of strains $\mathrm{A} / \mathrm{J}, \mathrm{SJL} / \mathrm{J}$ and $\mathrm{C} 57 \mathrm{BL} / 6 \mathrm{~J}$ were $21 \cdot 5 \pm 0 \cdot 1(\mathrm{~N}=19), 25 \cdot 0 \pm 0.6(\mathrm{~N}=8)$, and $25.4 \pm 0.3(\mathrm{~N}=23)$ days, respectively. Age at vaginal opening differed significantly amongst strains $(P<0.01)$. In the absence of males, $\mathrm{A} / \mathrm{J}$ females were younger at vaginal opening than were $\mathrm{SJL} / \mathrm{J}$ or $\mathrm{C} 57 \mathrm{BL} / 6 \mathrm{~J}$ females $(P<0 \cdot 01)$. The age at vaginal opening did not differ significantly between mice of strains $\mathrm{SJL} / \mathrm{J}$ and $\mathrm{C} 57 \mathrm{BL} / 6 \mathrm{~J}$.

\section{Experiment 2}

The timing of puberty was also determined in the presence of males. As shown in Table 1, age and weight at vaginal opening and at first vaginal plug differed significantly amongst strains 
Table 1. Age and weight of mice at vaginal opening and at first vaginal plug in the presence of males of the same strain

\begin{tabular}{|c|c|c|c|c|c|}
\hline $\begin{array}{l}\text { Strain } \\
\text { of mouse }\end{array}$ & $\begin{array}{c}\text { No. of } \\
\text { mice }\end{array}$ & $\begin{array}{l}\text { Age at } \\
\text { vaginal } \\
\text { opening } \\
\text { (days) }\end{array}$ & $\begin{array}{l}\text { Body wt } \\
\text { at vaginal } \\
\text { opening } \\
\text { (g) }\end{array}$ & $\begin{array}{c}\text { Age at } \\
\text { seminal } \\
\text { plug } \\
\text { (days) }\end{array}$ & $\begin{array}{l}\text { Body wt } \\
\text { at seminal } \\
\text { plug } \\
\text { (g) }\end{array}$ \\
\hline $\mathrm{A} / \mathbf{J}$ & 35 & $24 \cdot 2 \pm 0 \cdot 6^{a}$ & $12 \cdot 4 \pm 0.3^{\mathrm{a}}$ & $26 \cdot 1 \pm 0 \cdot 6^{a}$ & $13.7 \pm 0.4^{2}$ \\
\hline $\mathbf{S J L} / \mathbf{J}$ & 11 & $25 \cdot 3 \pm 0 \cdot 4^{a}$ & $12.4 \pm 0.5^{\mathrm{a}}$ & $26 \cdot 0 \pm 0.5^{a}$ & $12.7 \pm 0.5^{2}$ \\
\hline $\mathrm{C} 57 \mathrm{BL} / 6 \mathrm{~J}$ & 33 & $27.6 \pm 0.6^{\mathrm{b}}$ & $14 \cdot 1 \pm 0.4^{b}$ & $31 \cdot 4 \pm 1 \cdot 2^{b}$ & $15 \cdot 4 \pm 0.6$ \\
\hline
\end{tabular}

Values are mean \pm s.e.m. for the no. of mice shown.

Means within columns with different superscripts differ significantly $(P<0.05)$.

Table 2. Effect of age on strain differences in ovulatory response of mice to 5 i.u. PMSG and 5 i.u. hCG

\begin{tabular}{llcccc}
\hline $\begin{array}{l}\text { Age } \\
\text { (weeks) }\end{array}$ & Strain & $\begin{array}{c}\text { No. of } \\
\text { mice }\end{array}$ & $\begin{array}{c}\text { No. of } \\
\text { fresh ova }\end{array}$ & $\begin{array}{c}\text { No. of } \\
\text { old ova }\end{array}$ & $\begin{array}{c}\text { Body } \\
\text { weight } \\
\text { (g) }\end{array}$ \\
\hline $3 \cdot 5$ & A/J & 10 & $9 \cdot 3 \pm 1 \cdot 4^{\mathrm{a}}$ & $2 \cdot 9 \pm 1 \cdot 0^{\mathrm{a}}$ & $14 \cdot 7 \pm 0 \cdot 3^{\mathrm{a}}$ \\
4 & $\mathrm{~A} / \mathrm{J}$ & 12 & $6 \cdot 7 \pm 0 \cdot 4^{\mathrm{a}}$ & $3 \cdot 1 \pm 1 \cdot 2^{\mathrm{a}} \mathrm{b}$ & $16 \cdot 3 \pm 0 \cdot 4^{\mathrm{a}}$ \\
6 & $\mathrm{~A} / \mathrm{J}$ & 11 & $8 \cdot 0 \pm 1 \cdot 2^{\mathrm{a}}$ & $2 \cdot 6 \pm 1 \cdot 1^{\mathrm{a}}$ & $20 \cdot 7 \pm 0 \cdot 6^{\mathrm{c}}$ \\
8 & $\mathrm{~A} / \mathrm{J}$ & 14 & $12 \cdot 0 \pm 1 \cdot 0^{\mathrm{a}}$ & $4 \cdot 1 \pm 0 \cdot 8^{\mathrm{b}}$ & $21 \cdot 7 \pm 0 \cdot 4^{\mathrm{b}}$ \\
$3 \cdot 5$ & $\mathrm{C} 57 \mathrm{BL} / 6 \mathrm{~J}$ & 11 & $44 \cdot 1 \pm 3 \cdot 3^{\mathrm{c}}$ & $6 \cdot 0 \pm 1 \cdot 2^{\mathrm{a}}$ & $15 \cdot 9 \pm 0 \cdot 2^{\mathrm{c}}$ \\
4 & $\mathrm{C} 57 \mathrm{BL} / 6 \mathrm{~J}$ & 11 & $43 \cdot 7 \pm 3 \cdot 1^{\mathrm{c}}$ & $6 \cdot 0 \pm 0 \cdot 9^{\mathrm{b}}$ & $17 \cdot 3 \pm 0 \cdot 3^{\mathrm{a}}$ \\
6 & $\mathrm{C} 57 \mathrm{BL} / 6 \mathrm{~J}$ & 17 & $17 \cdot 5 \pm 1 \cdot 9^{\mathrm{c}}$ & $6 \cdot 4 \pm 0 \cdot 9^{\mathrm{b}}$ & $19 \cdot 1 \pm 0 \cdot 2^{\mathrm{a}}$ \\
8 & $\mathrm{C} 57 \mathrm{BL} / 6 \mathrm{JJ}$ & 10 & $21 \cdot 9 \pm 2 \cdot 0^{\mathrm{c}}$ & $4 \cdot 3 \pm 1 \cdot 0^{\mathrm{b}}$ & $20 \cdot 0 \pm 0 \cdot 5^{\mathrm{a}}$ \\
4 & $\mathrm{SJL} / \mathrm{J}$ & 7 & $39 \cdot 0 \pm 5 \cdot 4^{\mathrm{c}}$ & $1 \cdot 0 \pm 0 \cdot 6^{\mathrm{a}}$ & $17 \cdot 5 \pm 0 \cdot 8^{\mathrm{a}}$ \\
8 & $\mathrm{SJL} / \mathrm{J}$ & 11 & $26 \cdot 9 \pm 5 \cdot 8^{\mathrm{c}}$ & $0 \cdot 7 \pm 0 \cdot 3^{\mathrm{a}}$ & $21 \cdot 5 \pm 0 \cdot 2^{\mathrm{b}}$ \\
\hline
\end{tabular}

Values are mean \pm s.e.m. for the no. of mice shown.

a,b Within age, strains with different consecutive superscripts differ $(P<0.05)$.

${ }^{a, c}$ Within age, strains with different non-consecutive superscripts differ $(P<0.01)$.

$(P<0.01)$. Strain $\mathrm{A} / \mathrm{J}$ and $\mathrm{SJL} / \mathrm{J}$ females did not differ significantly in any of these puberty traits. $\mathrm{C} 57 \mathrm{BL} / 6 \mathrm{~J}$ females were older and heavier at vaginal opening and at first vaginal plug than were females of strains $\mathrm{A} / \mathrm{J}$ and $\mathrm{SJL} / \mathrm{J}(P<0.05)$.

\section{Experiment 3}

In mice of strains $\mathrm{A} / \mathrm{J}$ and $\mathrm{C} 57 \mathrm{BL} / 6 \mathrm{~J}$ the effects of strain, age and strain $\times$ age interaction on hormone-induced ovulation rate (Table 2$)$ were significant $(P<0 \cdot 001)$. The induced ovulation rate of $\mathrm{A} / \mathrm{J}$ mice increased insignificantly with increasing age while that of $\mathrm{C} 57 \mathrm{BL} / 6 \mathrm{~J}$ mice decreased significantly $(P<0.01)$ with increasing age. Nevertheless, C57BL/6J females ovulated more fresh ova than did $\mathrm{A} / \mathrm{J}$ females at all ages $(P<0.05$ to 0.0001$)$. SJL/J mice also ovulated more ova than $\operatorname{did} \mathrm{A} / \mathrm{J}$ mice at $4(P<0.0001)$ and $8(P<0.05)$ weeks of age.

While effects of strain on number of old ova (Table 2$)$ were significant $(P<0.0001)$, age and strain $\times$ age interaction effects were not significant. The effects of age and strain $\times$ age interaction on body weight (Table 2$)$ were highly significant $(P<0.001)$ while strain effects were not significant.

\section{Experiment 4}

Effects of strain, PMSG dose and the strain $\times$ PMSG dose interaction on hormone-induced ovulation rate (Fig. 1) were all significant $(P<0.0001)$. Strains differed dramatically in ovulatory 


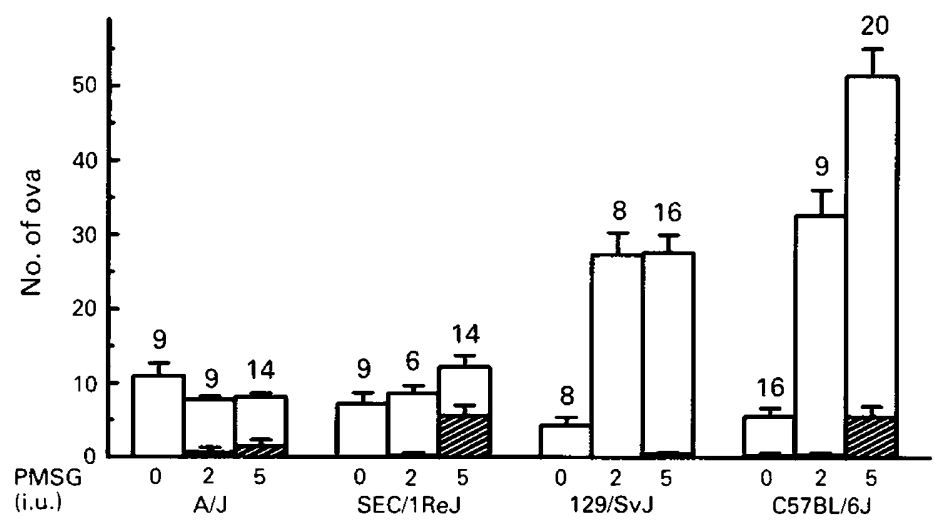

Strain of mouse

Fig. 1. Number of ova (open bars), and old ova (hatched bars) found in the oviduct of mice of different strains on Day 31 in response to increasing doses of PMSG at 28 days of age followed by 5 i.u. hCG at 30 days of age. Values are mean \pm s.e.m. for the no. of mice shown.

response to increasing doses of PMSG $(P<0.0001)$. A/J mice did not respond to increasing doses of PMSG, and induced ovulation rate of SEC/1 ReJ mice increased only slightly from 2 i.u. to 5 i.u. PMSG $(P<0 \cdot 1)$. The hormone-induced ovulation rate of $129 / \mathrm{SvJ}$ mice increased sharply from 0 to 2 i.u. PMSG $(P<0.0001)$, but showed no further increase with 5 i.u. The response of C57BL/6J females increased dramatically and in a linear manner for each dose of PMSG $(P<0 \cdot 0001)$.

The number of follicles matured by endogenous gonadotrophins (no PMSG) and ovulated in response to 5 i.u. hCG was relatively low in mice of all strains. In contrast, the number of follicles matured and ovulated in response to large doses of exogenous PMSG and hCG differed greatly amongst strains $(P<0.0001)$. These results show much larger genetic differences in the maximal responsiveness to large doses of exogenous gonadotrophins than differences in the sensitivity to the relatively small concentrations of endogenous gonadotrophins found in these young females. $\mathrm{A} / \mathrm{J}$ females matured and ovulated more ova in response to hCG alone at 30 days of age than did SEC/1ReJ $(P<0.05), 129 / \mathrm{SvJ}(P<0.01)$ and C57BL/6J $(P<0.01)$ females. The number of eggs matured by endogenous gonadotrophins and ovulated by exogenous $\mathrm{hCG}$ therefore did not correlate well with strain differences in the response to large doses of PMSG and hCG.

At each dose of PMSG, no differences were found amongst strains in the percentage of females with fresh ova in cumulus; all females injected with 2 i.u. PMSG and 5 i.u. hCG, or with 5 i.u. PMSG and 5 i.u. hCG, had ova in cumulus.

The numbers of old ova ovulated by increasing doses of PMSG are also shown in Fig. 1. A twoway analysis of variance of old ova showed significant effects of strain $(P<0.05)$, dose of PMSG $(P<0.0001)$ and the strain $\times$ dose interaction $(P=0.01)$. The increase in the number of old ova found in the oviduct with increasing doses of PMSG was small in strains $\mathrm{A} / \mathrm{J}$ and $129 / \mathrm{SvJ}$, but more dramatic in strains SEC/1ReJ and C57BL/6J. The number of old eggs matured by endogenous gonadotrophins and ovulated by the initial dose of PMSG was much smaller than the number of ova matured by 5 i.u. PMSG and ovulated by 5 i.u. hCG.

Strains did not differ in the percentage of mice with old ova in response to $5 \mathrm{i} . \mathrm{u}$. hCG. Out of 42 mice injected with hCG alone, only one C57BL/6J female had old ova in the oviduct on Day 31. Strains also did not differ in the percentage of mice with old ova in response to $2 \mathrm{i}$.u. PMSG followed by 5 i.u. hCG. However, strains did differ in the percentage of females with old eggs in the oviduct after treatment with 5 i.u. PMSG and 5 i.u. hCG $(P<0.01)$, being $21,71,19$, and $60 \%$ in strains A/J, SEC/1ReJ, 129/SvJ and C57BL/6J, respectively.

The mean \pm s.e.m. body weight of 31-day-old females in this experiment was $14.9 \pm 0.2 \mathrm{~g}$ and did not differ amongst strains. 


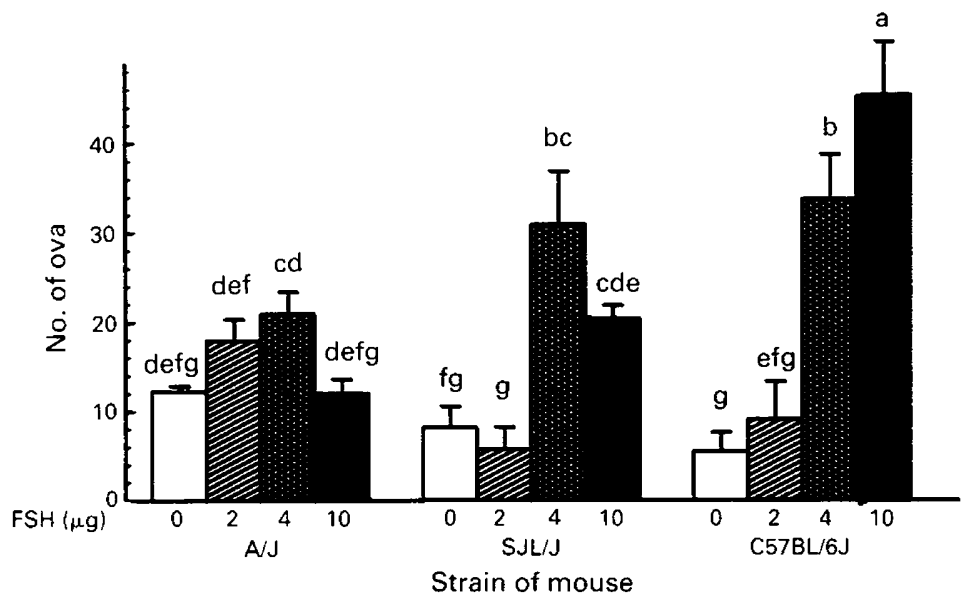

Fig. 2. Number of ova ovulated in response to increasing doses of oFSH injected twice daily starting at 28 days of age followed by $5 \mathrm{i}$.u. hCG at 30 days of age. Values are mean \pm s.e.m. for an average of 6 mice per point. Means with different superscripts differ significantly $(P<0.05)$.

\section{Experiment 5}

Effects of strain, FSH dose and the strain $\times$ FSH dose interaction on hormone-induced ovulation rate (Fig. 2$)$ were all significant $(P<0 \cdot 0001)$. Strains differed dramatically in ovulatory response to increasing doses of FSH $(P<0.0001)$. The number of eggs ovulated per mouse in response to 0 or $2 \mu \mathrm{g}$ FSH followed by 5 i.u. hCG did not differ between $\mathrm{C} 57 \mathrm{BL} / 6 \mathrm{~J}$ and $\mathrm{A} / \mathrm{J}$ mice. C57BL/6J mice ovulated more eggs than $\mathrm{A} / \mathrm{J}$ mice in response to 4 or $10 \mu \mathrm{g} \mathrm{FSH}$ followed by $5 \mathrm{i} . \mathrm{u}$. hCG $(P<0.05)$. The number of eggs ovulated by $\mathrm{SJL} / \mathrm{J}$ mice in response to each dose of $\mathrm{FSH}$ followed by $5 \mathrm{i} . \mathrm{u}$. hCG did not differ from that of $\mathrm{A} / \mathrm{J}$ mice.

The mean \pm s.e. number of old ova ovulated per mouse in response to $0,2,4$ or $10 \mu \mathrm{g}$ FSH was $0 \cdot 0 \pm 0 \cdot 0,2 \cdot 5 \pm 1 \cdot 1,2 \cdot 0 \pm 1 \cdot 0$, and $7 \cdot 4 \pm 2 \cdot 0$, respectively in $\mathrm{A} / \mathrm{J}$ mice; $0 \cdot 0 \pm 0 \cdot 0,3 \cdot 4 \pm 2 \cdot 1$, $1.4 \pm 0.6$, and $1.6 \pm 1.4$, respectively in $\mathrm{SJL} / \mathrm{J}$ mice; and $0.0 \pm 0.0,1.0 \pm 0.4,0.9 \pm 0.6$, and $0 \cdot 8 \pm 0 \cdot 7$, respectively in $\mathrm{C} 57 \mathrm{BL} / 6 \mathrm{~J}$ mice. A two-way analysis of variance of old ova showed significant effects of strain $(P<0.01)$ and dose of FSH $(P<0.01)$, but not of the strain $\times$ dose interaction. Strains did not differ in the percentage of mice with old ova in response to 0,2 or $4 \mu \mathrm{g}$ FSH followed by 5 i.u. hCG. In contrast, strains differed in the number of old eggs found in the oviduct after treatment with $10 \mu \mathrm{g} \mathrm{FSH}$ and 5 i.u. hCG $(P<0.05)$. No old ova were found in the oviduct of any of the 15 mice injected with hCG alone $(0 \mu \mathrm{g} \mathrm{FSH})$.

The mean \pm s.e.m. body weight of 31-day-old females in this experiment was $15.8 \pm 0.2 \mathrm{~g}$. Body weight was affected by strain $(P<0.05)$, but not by dose of FSH or strain $\times$ dose interaction.

\section{Discussion}

Previous studies (Spearow, 1988) have identified major genetic differences in hormone-induced ovulation rate between mouse strains $\mathrm{A} / \mathrm{J}$ and $\mathrm{SJL} / \mathrm{J}$ as well as between strains $\mathrm{A} / \mathrm{J}$ and $\mathrm{C} 57 \mathrm{BL} / 6 \mathrm{~J}$ which are due to the action of a small number of loci.

Several observations in the present study suggest that these major genetic differences in hormoneinduced ovulation rate in response to high doses of gonadotrophins were not due to differences in timing of puberty per se. Hormone-induced ovulation rate is affected by age (Zarrow \& Wilson, 1961) and ovulation rate increases for several succeeding oestrous cycles after puberty in several species. It was therefore possible that high hormone-induced ovulation rate in $\mathrm{SJL} / \mathrm{J}$ and $\mathrm{C} 57 \mathrm{BL} / 6 \mathrm{~J}$ mice could 
have been due to their reaching puberty and thereby maturing follicles earlier than $\mathrm{A} / \mathrm{J}$ females with low induced ovulation rate. However, the present results show that, in the absence of males, vaginal opening occurs earlier in $\mathrm{A} / \mathrm{J}$ than in $\mathrm{SJL} / \mathrm{J}$ or $\mathrm{C} 57 \mathrm{BL} / 6 \mathrm{~J}$ females. In the presence of males, vaginal opening and first oestrus occur earlier in $\mathrm{A} / \mathrm{J}$ and $\mathrm{SJL} / \mathrm{J}$ females than in C57BL/6J females. The difference in the results of these two experiments suggests that these strains may also differ in sensitivity to the induction of puberty by the male, or in the ability of males to induce puberty (Eleftheriou et al., 1972; Eleftheriou \& Kristal, 1974; Champlin et al., 1980). Most importantly, in the absence of the male, Exp. 1 shows that the strains with a high induced ovulation rate, SJL/J and $\mathrm{C} 57 \mathrm{BL} / 6 \mathrm{~J}$, reach puberty later than does that with a low induced ovulation rate, A/J. Since SJL/J and $\mathrm{C} 57 \mathrm{BL} / 6 \mathrm{~J}$ mice reach puberty later, it seems highly unlikely that mice of these strains could mature more follicles than $\mathrm{A} / \mathrm{J}$ mice due to elevated endogenous gonadotrophins at 25 or 28 days of age. Older, clearly post-pubertal, C57BL/6J and SJL/J females also ovulated more ova after exogenous gonadotrophins than did $\mathbf{A} / \mathbf{J}$ females. Therefore, the observed superiority in hormoneinduced ovulation rate of $\mathrm{C} 57 \mathrm{BL} / 6 \mathrm{~J}$ and $\mathrm{SJL} / \mathrm{J}$ mice over $\mathrm{A} / \mathrm{J}$ mice at 4 weeks of age cannot be explained simply by a difference in timing of puberty in these strains.

These results also suggest that the observed major genetic differences in hormone-induced ovulation rate in response to high doses of gonadotrophins were not due to differences in maturation and ovulation of follicles by endogenous gonadotrophins. Experiment 4 clearly shows that the vast majority of mice of strains A/J, SEC/1ReJ, 129/SvJ and C57BL/6J had not been exposed to high enough concentrations of endogenous gonadotrophins before Day 30 to ovulate.

Relatively small differences were found amongst strains in number of follicles matured by endogenous gonadotrophins and ovulated by exogenous gonadotrophins. This contrasts with the tremendous amount of genetic variation in hormone-induced ovulation rate found in response to intermediate and high doses of exogenous gonadotrophins. The relative magnitude of the genetic differences in eggs ovulated in response to hCG alone or old eggs ovulated in response to the initial dose of PMSG was similar to previously reported strain differences in natural ovulation rate (Falconer, 1960; Falconer et al., 1961; Durrant et al., 1980; Spearow \& Bradford, 1983). In the present study, the largest difference amongst strains in mean number of eggs ovulated in response to hCG alone was the 6.6-egg (1.5-fold, non-significant) difference between A/J and 129/SVJ mice. The relatively small observed strain differences in response to hCG alone are dwarfed by the 37-44.6-egg difference amongst strains $(P<0.001)$ in response to 5 i.u. PMSG and 5 i.u. hCG. Furthermore, females of strains with the greatest ovarian response to high doses of PMSG and hCG did not ovulate more ova in response to hCG alone than did strains with the lowest ovarian responsiveness to gonadotrophins. This is seen by the response to hCG alone at 30 days of age: females of strains $\mathrm{SEC} / 1 \mathrm{ReJ}, 129 / \mathrm{SvJ}$ and C57BL/6J all matured and ovulated fewer eggs than $\mathrm{did} \mathrm{A} / \mathrm{J}$ females. These results clearly show that the major genetic differences in response to large doses of PMSG and hCG were not due to strain differences in the maturation of follicles by endogenous gonadotrophins and ovulation by exogenous gonadotrophins.

The results of the present study also indicated that the superiority of the ovulatory response of $\mathrm{C} 57 \mathrm{BL} / 6 \mathrm{~J}$ and $\mathrm{SJL} / \mathrm{J}$ mice over that of $\mathrm{A} / \mathrm{J}$ mice was maintained over a wide range of ages, varying from 3.5 to 8 weeks. Nevertheless, the magnitude of strain differences in hormone-induced ovulation rate of older females (6-8 weeks) was smaller than that found in younger ( $3 \cdot 5-4$ weeks) females. The relative decline in the superiority of ovulatory response of lines $\mathrm{SJL} / \mathrm{J}$ and $\mathrm{C} 57 \mathrm{BL} / 6 \mathrm{~J}$ over that of $\mathrm{A} / \mathrm{J}$ with increasing age may be due to the injection of gonadotrophins when some older females were at less responsive stages of the oestrous cycle (Greenwald, 1962), or the decline in the number of large preantral to small antral follicles with increasing age (Pedersen, 1970). These factors and extra-ovarian controls of ovarian function may also partly account for much of the decreased mean induced ovulation rate in older mice as found by Zarrow \& Wilson (1961) and in the present study.

The present study found dramatic differences among strains in the dose-response to increasing doses of PMSG. These results agree with previously reported but less dramatic strain differences in hormone-induced ovulation rate in response to increasing doses of exogenous gonadotrophins 
(Land \& Falconer, 1969; Bindon \& Pennycuik, 1974). While it seems unlikely, due to the variability in dose responses to PMSG (Land, 1970), it is possible that other doses of PMSG or other hormones might give different patterns of response. Hormone-induced ovulation rate has been shown to be affected by the dose of gonadotrophins administered and the ratio of FSH to LH activity (Bindon \& Pennycuik, 1974; Sreenan \& Gosling, 1977; Donaldson, 1984; Lindsell et al., 1985; Chupin et al., 1985).

Since the observed genetic differences in hormone-induced ovulation rate might have been due to genetic differences in the ability to respond to PMSG but not to FSH, strain differences in the ovulatory response to increasing doses of FSH were also examined in Exp. 5. While the ovulatory responses of SJL/J to high doses of FSH tended to be higher than that of $\mathrm{A} / \mathrm{J}$ mice, with the small number of animals examined, these differences were not significant. In contrast, the ovulatory responses of $\mathrm{C} 57 \mathrm{BL} / 6 \mathrm{~J}$ mice to high doses of $\mathrm{FSH}$ were significantly higher than that of $\mathrm{A} / \mathrm{J}$ mice. Indeed, $\mathrm{C} 57 \mathrm{BL} / 6 \mathrm{~J}$ ovulated $3 \cdot 8$-fold more eggs in response to $10 \mu \mathrm{g} \mathrm{FSH}$ followed by $5 \mathrm{i}$.u. hCG than did $\mathrm{A} / \mathrm{J}$ mice. Furthermore, within strains, ovulation rate increased significantly in response to increasing doses of $\mathrm{FSH}$ in $\mathrm{SJL} / \mathrm{J}$ and $\mathrm{C} 57 \mathrm{BL} / 6 \mathrm{~J}$ but not in $\mathrm{A} / \mathrm{J}$ mice. These results clearly show that $\mathrm{C} 57 \mathrm{BL} / 6 \mathrm{~J}$ females are more responsive than $\mathrm{A} / \mathrm{J}$ females to large doses of exogenous gonadotrophins, regardless of whether the gonadotrophins are PMSG or FSH.

The highly significant strain $\times$ dose interaction for hormone-induced ovulation rate in Exp. 4 provides further evidence that the observed genetic differences in this trait between $\mathrm{A} / \mathrm{J}$ and $\mathrm{C} 57 \mathrm{BL} /$ $6 \mathrm{~J}$ mice were due to differences in ovarian responsiveness to gonadotrophins. In response to hCG alone, C57BL/6J females ovulated fewer ova than did A/J females. However, in response to 2 or 5 i.u. PMSG followed by hCG, C57BL/6J ovulated far more ova than did A/J females. These results clearly show that the high PMSG-hCG-induced ovulation rate of $\mathrm{C} 57 \mathrm{BL} / 6 \mathrm{~J}$ mice cannot be due to the maturation of a large number of follicles by endogenous gonadotrophins and ovulation by hCG. These results suggest that the observed genetic differences in hormone-induced ovulation rate are due to differences in the induction of follicular maturation or the prevention of follicular atresia.

It was also possible that the low hormone-induced ovulation rate of $\mathrm{A} / \mathrm{J}$ mice was due to a total inability of the ovaries of this strain to bind and respond to hCG. This is unlikely for three reasons. Firstly, A/J ovaries are capable of binding hCG (Spearow et al., 1983). Secondly, hCG stimulates steroidogenesis in vitro in A/J ovaries (Spearow et al., 1985). Finally, in Exps 4 and 5 of the present study A/J mice ovulated as many or more eggs in response to $5 \mathrm{i} . \mathrm{u}$. hCG alone as did mice of strains with high PMSG and hCG-induced ovulation rates. Therefore, $\mathbf{A} / \mathbf{J}$ females are clearly able to bind hCG, and respond to hCG.

It is likely that genetic variation in ovarian responsiveness to gonadotrophins, similar to that found by Spearow (1988) and in the present study, also exists in other species. This has two major implications for the testing of the effects of hormone and drug treatments on ovulation rate. First, the coefficient of variation of hormone-induced ovulation rate should be lower for inbred lines of $F_{1}$ generations of inbred lines than for that of $F_{2}$ or outbred populations. Therefore, the use of highly inbred lines or $F_{1} s$ of highly inbred lines should enhance the efficiency of experiments examining ovarian responsiveness to exogenous hormones. Secondly, these results show that the ovulatory response to a drug or hormone treatment often differs between strains or genotypes. Therefore, to develop a treatment which results in a more uniform ovulatory response in a non-inbred population, treatments should be tested on several widely divergent ovulatory response genotypes.

The presence of genetic variation in ovarian responsiveness to gonadotrophins in this and other species also has implications for animal breeders and geneticists interested in selecting for increased reproductive performance. These results, and those of Spearow (1988), suggest that breeders interested in rapidly increasing natural or induced ovulation rate should screen a population to confirm the inclusion of a high frequency of favorable alleles controlling this trait before initiating selection. For example, if a base population is fixed with ovarian response genes similar to those found in $\mathrm{A} / \mathrm{J}$ or SEC/I ReJ mice, efforts to increase hormone-induced ovulation rate via selection would be very 
slow or futile regardless of the selection intensity. In contrast, if a breeder confirmed that the base population contained a high frequency of high ovarian response alleles similar to those found in $\mathrm{C} 57 \mathrm{BL} / 6 \mathrm{~J}$ mice, the response to selection for induced ovulation rate would be much greater and faster.

In summary, the present study shows that the dramatic genetic differences in hormone-induced ovulation rate were due to differences in the response to increasing doses of exogenous gonadotrophins. Further studies will be required to determine whether these genetic differences in ovarian responsiveness to gonadotrophins are due to differences in factors such as the half-life of gonadotrophins, follicular populations, induction of follicle maturation, induction of atresia, FSH and LH receptor characteristics, and ovarian production of cAMP and steroids.

This research was supported by the College of Agricultural and Life Sciences Hatch grant (WIS-2848), and in part by NIH Grant (HD18889-02). I thank Dr Robert Erickson and Dr Rees Midgley for guidance and sharing their laboratories; Laura Herbon, Pete Smith, Dawn Speers, Sherie Ziemer, Jeff Durkin and Tammy Willborn for helping with the mice; and Julie Busby, Judy Petersen, Beth Robbins and Dr Scott Newman for assistance in the preparation of this manuscript.

\section{References}

Bindon, B.M. \& Pennycuik, P.R. (1974) Differences in ovarian sensitivity of mice selected for fecundity. $J$. Reprod. Fert. 36, 221-224.

Brown, M.A. \& Forsythe, A.B. (1974) The small sample behavior of some statistics which test the equality of several means. Technometrics 16, 129-132.

Champlin, A.K., Beamer, W.G., Carter, S.C., Shire, J.G.M. \& Whitten, W.K. (1980) Genetic and social modification of mating patterns of mice. Biol. Reprod. 22, 164-172.

Chupin, D., Combarnous, Y. \& Procureur, R. (1985) Different effect of LH on FSH-induced superovulation in two breeds of cattle. Theriogenology 23, 184, Abstr.

Dixon, W.J. (1983) Description of groups with histograms and analysis of variance. In $B M D P$ Statistical Software, pp. 105-115. Ed. W. J. Dixon.

Donaldson, L.E. (1984) Dose of FSH-P as a source of variation in embryo production from superovulated cows. Theriogenology 22, 205-212.

Durrant, B.S., Eisen, E.J. \& Ulberg, L.C. (1980) Ovulation rate, embryo survival and ovarian sensitivity to gonadotrophins in mice selected for litter size and body weight. J. Reprod. Fert. 59, 329-339.

Eleftheriou B.E. \& Kristal, M.B. (1974) A gene controlling bell- and photically-induced ovulation in mice. $J$. Reprod. Fert. 38, 41-47.

Eleftheriou, B.E., Bailey, D.W. \& Zarrow, M.X. (1972) A gene controlling male pheromonal facilitation of PMSG-induced ovulation in mice. J. Reprod. Fert. 31, 155-158.

Falconer, D.S. (1960) The genetics of litter size in mice. $J$. cell. comp. Physiol. 56 (Suppl. 1), 153-167.

Falconer, D.S., Edwards, R.G., Fowler, R.E. \& Roberts, R.C. (1961) Analysis of differences in the numbers of eggs shed by the two ovaries of mice during natural oestrus or after superovulation. J. Reprod. Fert. 2, 418-437.
Greenwald, G.S. (1962) Analysis of superovulation in the adult hamster. Endocrinology 71, 378-389.

Land, R.B. (1970) Reduction of the ovulation rate of the mouse by treatment with small doses of pregnant mares' serum gonadotrophin. J. Reprod. Fert. 21, 243-247.

Land, R.B. \& Falconer, D.S. (1969) Genetic studies of ovulation rate in the mouse. Genet. Res. 13, 25-46.

Lindsell, C.E., Pawlyshyn, V., Bielanski, A. \& Mapletoft, R.J. (1985) Superovulation of heifers with FSH-P beginning on four different days of the cycle. Theriogenology 23, 203, Abstr.

Pedersen, T. (1970) Follicle kinetics in the ovary of the cyclic mouse. Acta endocr., Copenh. 64, 304-323.

Spearow, J.L. (1988) Major genes control hormoneinduced ovulation rate in mice. J. Reprod. Fert. 82, $773-783$.

Spearow, J.L. \& Bradford, G.E. (1983) Genetic variation in spontaneous ovulation rate and $\mathrm{LH}$ receptor induction in mice. J. Reprod. Fert. 69, 529-537.

Spearow, J.L., Herbon, L., Malone, E. \& Fields, S. (1983) Genetic variation in LH receptor characteristics of mice. J. Anim. Sci. 57 (Suppl. 1), 357A, Abstr.

Spearow, J.L., Bednarek, S., Piccolo, J. \& Trost, B. (1985) Do genetic differences in steroidogenesis mediate major genetic differences in hormone induced ovulation rate in mice? Biol. Reprod. 30, Suppl. 1, 198A, Abstr.

Sreenan, J.M. \& Gosling, J.P. (1977) The effect of cycle stage and plasma progesterone level on the induction of multiple ovulations in heifers. J. Reprod. Fert. 50, 367-369.

Zarrow, M.X. \& Wilson, E.D. (1961) The influence of age on superovulation in the immature rat and mouse. Endocrinology 69, 851-855.

Received 16 September 1987 